\title{
The Ecosystem Service Valuation and Federal Conservation Special Issue of ARER
}

\section{Daniel Hellerstein $\odot$ and Luanne Lohr}

\begin{abstract}
Valuing the ecosystem services delivered by conservation and stewardship programs is of interest within USDA and across the federal government. Answering these types of questions requires accurate and scientifically sound measures of Ecosystem Service Values (ESVs). While there is a rich literature on valuation of nonmarket goods, it is often difficult to use for the ESVs provided by USDA and other federal agencies. To advance understanding of the use of ESVs in conservation programs, this special issue of ARER presents selected papers from a 2019 workshop entitled "Applications and Potential of Ecosystem Services Valuation within USDA - Advancing the Science."
\end{abstract}

Keywords: Conservation policy, Ecosystem Service Values, nonmarket values, USDA, conservation policy, USFS valuation

The United States Department of Agriculture (USDA) spends over $\$ 5$ billion yearly to support and improve the ecosystem services on private lands (primarily through voluntary agricultural programs). USDA also owns and controls substantial public lands on which ecosystem services are a planning and management consideration (primarily through the 193 million acres managed by the U.S. Forest Service [USFS]).

Valuing the ecosystem services delivered by conservation and stewardship programs is of interest within USDA and across the federal government. A question of importance is "what has the public gained from USDA conservation and stewardship investments?" That is: what is the ecosystem services value of USDA's conservation and stewardship policies and programs?

Examples of programs include:

- Targeting farmland conservation practices: which conservation practices should be placed where in order to yield the greatest public benefit (for example, by changes in farm management supported by the Environmental Quality Incentive Program [EQIP] or converting land use

Daniel Hellerstein, Agricultural Economist, USDA Economic Research Service; Luanne Lohr, National Program Lead, Economics Research, US Forest Service.

Corresponding author: Daniel Hellerstein, Agricultural Economist, USDA Economic Research Service, daniel.hellerstein@usda.gov

Agricultural and Resource Economics Review 49/1 (April 2020) 1-6

(C) The Author(s) 2020. This is an Open Access article, distributed under the terms of the Creative

Commons Attribution licence (http://creativecommons.org/licenses/by/4.0/), which permits unrestricted re-use, distribution, and reproduction in any medium, provided the original work is 
from active agriculture to a more conserving cover via the Conservation Reserve Program [CRP]) ${ }^{1}$

- Guiding public land management: how should ecological and cultural/ human needs be balanced to meet multiple use public goals and meet shared stewardship objectives?

- Evaluating broad conservation programs and policies: are the benefits at least as great as the costs for programs like environmental markets and the Collaborative Forest Landscape Restoration Program?

Answering these types of questions requires accurate and scientifically sound measures of Ecosystem Service Values (ESVs). Ecosystem services are often "nonmarket" goods and services. They are not readily traded in markets, often due to their public-goods nature (non-competitive in consumption and non-excludable). Developing accurate ESV estimates raises considerable and challenging methodological and empirical issues. These include:

$\bigcirc$ recognition of dispersed and multiple ecosystem impacts that can flow from discrete actions

$\bigcirc$ challenges of measuring impacts of widely dispersed changes in land use driven by "working lands" programs (changes in lands managed for production) and "land retirement" programs (non-permanent conversions)

$\bigcirc$ affected populations can vary greatly both in size and concerns

$\bigcirc$ cultural and biophysical services may interact

$\bigcirc$ nonlinearities, complementarities, and substitution effects of program/policies

$\bigcirc$ ease of updating estimates (as the population and environment change)

$\bigcirc$ capacity to be used when designing policy/program actions

capacity to be used for ex post valuations of actions

There is a rich literature on valuation of non-market goods, and ever-growing environmental and resource use data (see the Appendix for a listing of Ecosystem Service valuation resources provided by USDA and other federal

\footnotetext{
1 The 2018 Farm Act allocates approximately $\$ 5$ billion/year to conservation programs. Land retirement program funding includes up to 27 million acres in the Conservation Reserve Program and $\$ 450$ million for the Agricultural Conservation Easement Program. Working land programs include over $\$ 1.75$ billion for the Environmental Quality Incentives Program (EQIP) and over $\$ 700$ million for the Conservation Stewardship Program. Further details can be found at Claassen et al. (2018) or https://www.ers.usda.gov/agriculture-improvement-act-of-2018highlights-and-implications/conservation/.
} 
agencies). However, the methods and analyses described in this literature are often difficult or impractical to use to estimate ESVs provided by USDA and other federal agencies. For example, the ESVs associated with USDA programs and policies on private lands are often characterized by their "non-point" nature: myriad small impacts diffused across a wide landscape that can have individually small effects on the well-being of a large and diverse population. Conversely, a single management decision can have impacts beyond the limited geography on which the program or activity is implemented.

The federal government both funds conservation on private lands and holds lands in trust for the public. Agencies are authorized by legislation to manage public lands for specific uses. Management decisions are constrained by mission, authorities, regulations, and budget, as well as Administration directives. Effective management considers whole landscape effects. Since ecological units are not drawn according to political boundaries, coordination with other public trust entities and private landowners is critical to achieving management objectives. Agencies actively solicit and incorporate public input before finalizing regulations or management plans.

In particular, the U.S. Forest Service mission is to "sustain the health, diversity, and productivity of the nation's forests and grasslands to meet the needs of present and future generations." Sustaining national forests and grasslands implies the need to preserve and maintain the productive base of natural capital. Meeting the needs of future generations indicates that option value, as well as current valuation, is a consideration. The Forest Service has undergone an evolution in management of public lands, with current emphasis on trading off ecosystem services across space and time. ${ }^{2}$ Human dimensions of ecosystems are explicitly accounted for in the 2012 Forest Service Planning Rule, introducing an inherently difficult challenge in developing appropriate metrics to value goods and services for end users.

Public lands jointly produce multiple ecosystem services, some incompletely valued or not valued at all in markets. Market goods (e.g., timber, water quantity, grazing acres, non-timber forest products) are readily priced but may not be easily valued if market information is incomplete. Local and global nonmarket goods and services (e.g., flood control, carbon sequestration, and recreation experiences) are critical to balancing the multiple-use mission of the Forest Service but are not easily valued. Managers at National Forests typically seek an optimal mix of private (priced) and public (unpriced) ecosystem services for users. Developing a common metric makes management choices clearer and more defensible. Nonmarket valuation can help understand public investments by aiding the Forest Service to fully account for ecosystem services.

Supporting conservation on private land shares many of these same challenges. USDA's agricultural conservation programs are almost always

\footnotetext{
2 See Kline et al. (2013) for a complete review of management evolution on U.S. Forest Service lands.
} 
voluntary; there is often more interest in the program than available funds. Thus agencies can use a variety of tools to target in a cost-effective manner. But measuring the effectiveness of a program (such as the CRP) implies measuring its impact on the provision of ecosystem services. Nonmarket valuation can help managers improve cost effectiveness by illuminating what parcels and practices to target.

To advance understanding of the use of ESVs in conservation programs, several USDA agencies sponsored an April 2019 workshop. Entitled "Applications and Potential of Ecosystem Services Valuation within USDA Advancing the Science,"3 the two-day workshop featured 20 presentations on a broad variety of topics relevant to ecosystem service valuation. This special issue of Agricultural and Resource Economics Review presents a curated subset ${ }^{4}$ of the papers presented at the workshop.

Leroy Hansen, in "What the Past Suggests about Future Development of Ecosystem Service Values Applicable to USDA Agricultural Program Evaluations," provides a broad overview on ESV research and its applicability to USDA program benefit analysis. He notes limitations of current research and summarizes a set of ESVs developed by the Economic Research Service so as to illustrate what methodologies have been used and what approaches will improve the reliability and spatial resolution.

Robert Johnston et al., in "Using Meta-Analysis for Large-Scale Ecosystem Service Valuation: Progress, Prospects, and Challenges," discusses prospects and challenges related to the use of meta-regression models for ecosystem service benefit transfer. A case study using alternative riparian buffer restoration scenarios in New Hampshire highlights the challenges of using meta-regression benefits transfer when quantifying ecosystem service values.

Donald English et al., in "A Review of the Forest Service's National Visitor Use Monitoring (NVUM) Program," describe the history and science background of the NVUM data of recreation use on USFS lands. Examples that use this data are presented, ranging from work on the effects of natural disasters to development of expenditure and benefit's transfer applications. USFS uses these data for biennial estimates of jobs and income effects of recreation spending on National Forests.

Gregory Frey et al., in "Estimating the Value of Forests for Provisioning NonTimber Forest Products to Market: Concepts, Approaches, and Case Studies," analyzes ESVs and non-timber forest products. Though some have market value, non-timber forest products are often considered nonmarket goods, and are provided via informal markets, with harvest and consumption throughout the U.S. for numerous purposes, and have been generally neglected in USDA

3 The workshop proceedings can be found at http://www.narea.org/esvworkshopproceedings.

4 All authors were given an opportunity to submit papers for this special edition of ARER. Several had commitments with other journals, several authors did not extend their workshop proceedings into journal-quality papers, and several papers did not survive the editorial process. 
policies. Two case studies illustrate the difficulties in data collection, quantifying production, and measuring costs and benefits.

Lorie Srivastava et al., in "How Will Climate Change Affect the Provision and Value of Water from Public Lands in Southern California through the 21st Century?," estimate the ecosystem service value of water supplied by the San Bernardino National Forest in Southern California under climate change projections through the 21st century. Consumer welfare impacts are discussed, as water supply changes under different climate scenarios.

Robert Haight et al., in "Estimating the Present Value of Carbon Sequestration in U.S. Forests, 2015-2050, for Evaluating Climate Change Mitigation Federal Policies," uses detailed forest inventory data to evaluate carbon sequestration benefits from federal policy alternatives. Results suggest that afforestation and reforestation would provide the greatest marginal increase in carbon benefits.

Thomas Holmes, in "Perspectives on Advances in Ecosystem Service Valuation," addresses the 21st-century challenge of conducting landscapescale studies to gauge the impacts of anticipated changes in ecosystem services on the well-being of Americans. Issues of funding reliability, the use of non-traditional data, and dissemination of findings are considered.

These papers broadly frame the state of science on how ESVs are measured, and could be applied, to the design and implementation of USDA programs. While limited, this body of work continues to expand. For example, USFS researchers are actively considering a gamut of issues, such as recreational use of forest lands, non-timber forestland outputs, water supply, and carbon sequestration. The possibilities of leveraging existing data, such as through advances in meta-analysis or the use of non-traditional data such as social media, can help fill in gaps. Not surprisingly, much work needs to be donein addition to the prospects and needs being non-trivial, so too are questions on how to structure funding initiatives and how to communicate findings. We hope these papers generate new interest and expand research in our understanding of ESVs and how they can be measured and applied in public policy.

\section{Acknowledgments}

The authors acknowledge the contributions of Leroy Hansen (USDA ERS retired) and Robbin Shoemaker (USDA NIFA retired), both of whom were instrumental in organizing the 2019 workshop. Chris Hartley (USDA OCE) provided support and encouragement. And, of course, the presenters at the workshop-including those whose work does not appear in this special journal.

\section{Disclaimer}

The findings and conclusions in this article are those of the authors and should not be construed to represent any official USDA or U.S. Government 
determination or policy. This research was supported by the U.S. Department of Agriculture, Economic Research Service and Forest Service.

\section{Financial Disclosure}

Funding for the workshop was provided by the USDA Economic Research Service, in collaboration with the Association of Environmental and Resource Economists (Cooperative Agreement 58-6000-8-0056). Funding for administrative support for the workshop was provided by the United States Forest Service. Funding for a special issue of ARER was provided by the USDA Economic Research Service, and the USDA Office of the Chief Economist to the University of Connecticut (Non-Assistance Cooperative Agreement 58-6000-9-0053-R).

\section{Conflicts of Interest}

None

\section{Supplementary material}

The supplementary material for this article can be found at https://doi.org/10. $1017 /$ age.2020.2

\section{References}

Claassen, R., D. Hellerstein, and S. Wallander. 2018. "2018 Farm Act Retains Conservation Programs But Could Reduce Payments for Land Retirement”. Amber Waves. Dec 022019. https://www.ers.usda.gov/amber-waves/2019/december/2018-farm-act-retains-conser vation-programs-but-could-reduce-payments-for-land-retirement/.

Kline, J. M. Mazzotta, T. Spies, M. Harmon. 2013. "Applying the Ecosystem Services Concept to Public Land Management." Agricultural and Resource Economics Review 42(1): 139-158. 